Supplement of Hydrol. Earth Syst. Sci., 24, 5231-5249, 2020

https://doi.org/10.5194/hess-24-5231-2020-supplement

(c) Author(s) 2020. This work is distributed under

the Creative Commons Attribution 4.0 License.

(c) (1)
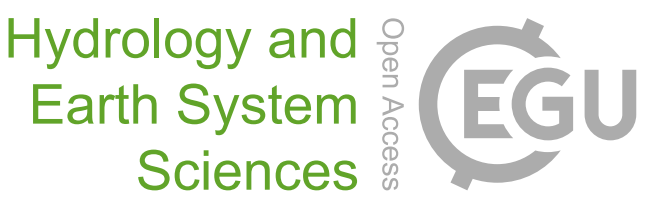

Supplement of

\title{
Interplay of changing irrigation technologies and water reuse: example from the upper Snake River basin, Idaho, USA
}

Shan Zuidema et al.

Correspondence to: Shan Zuidema (shan.zuidema@unh.edu)

The copyright of individual parts of the supplement might differ from the CC BY 4.0 License. 


\section{Supplement}

\section{Contents of supplement}

1) Irrigation technologies in the Water Balance Model

2) Lumped aquifer representation

3) Crop classifications

4) Springs outflow data

5) Validation of Water Balance Model for baseline

6) Fate of gross irrigation for all parameterizations

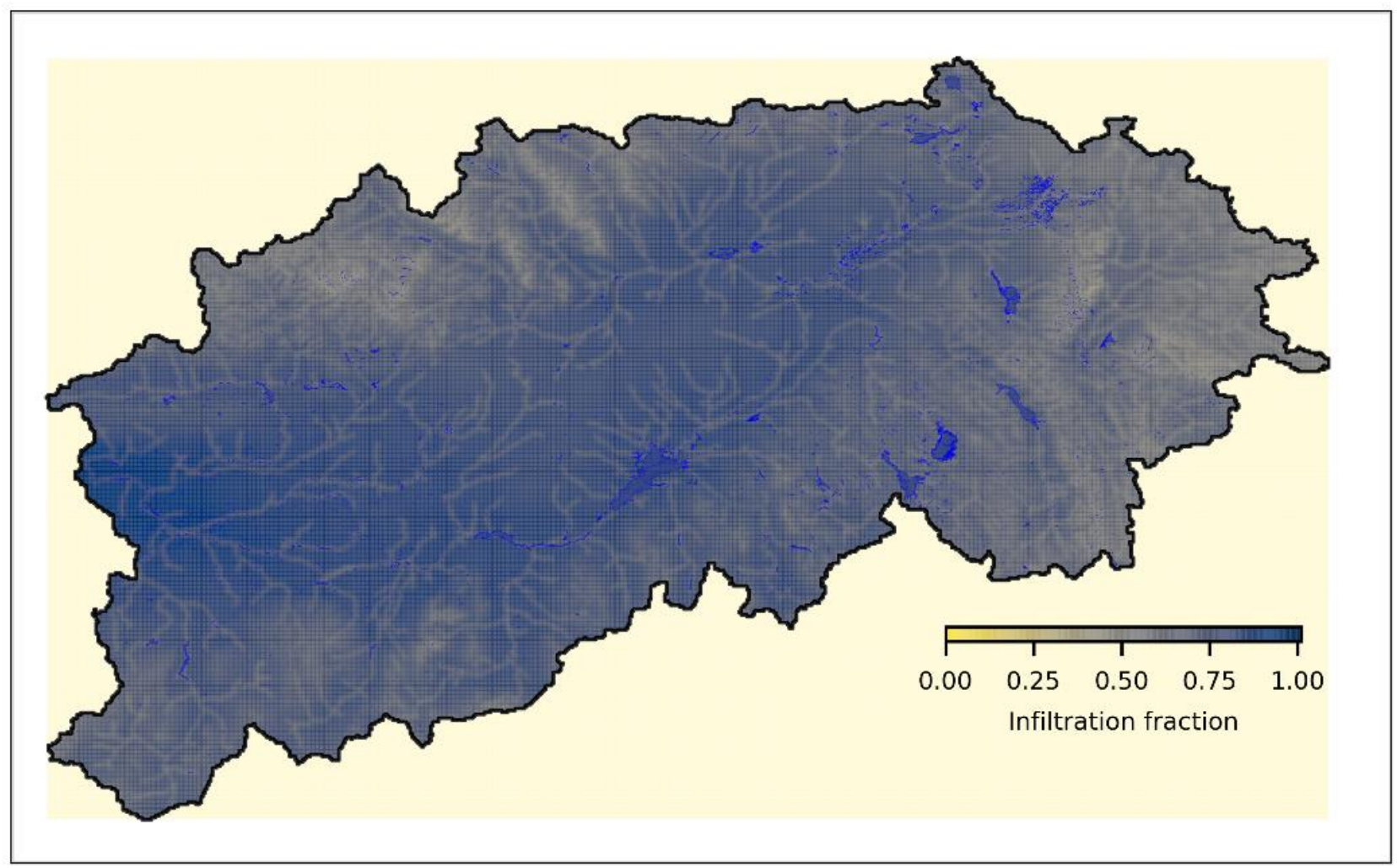

10 Figure S1: Infiltration fraction defining the proportion of saturation excess that infiltrates to shallow and deep groundwater reservoirs; the complement runs off the soil surface. The distribution of infiltration fraction qualitatively exhibits observations that runoff occurs proximal to moderate size rivers (greater than order 4), and tends to decrease with elevation. 


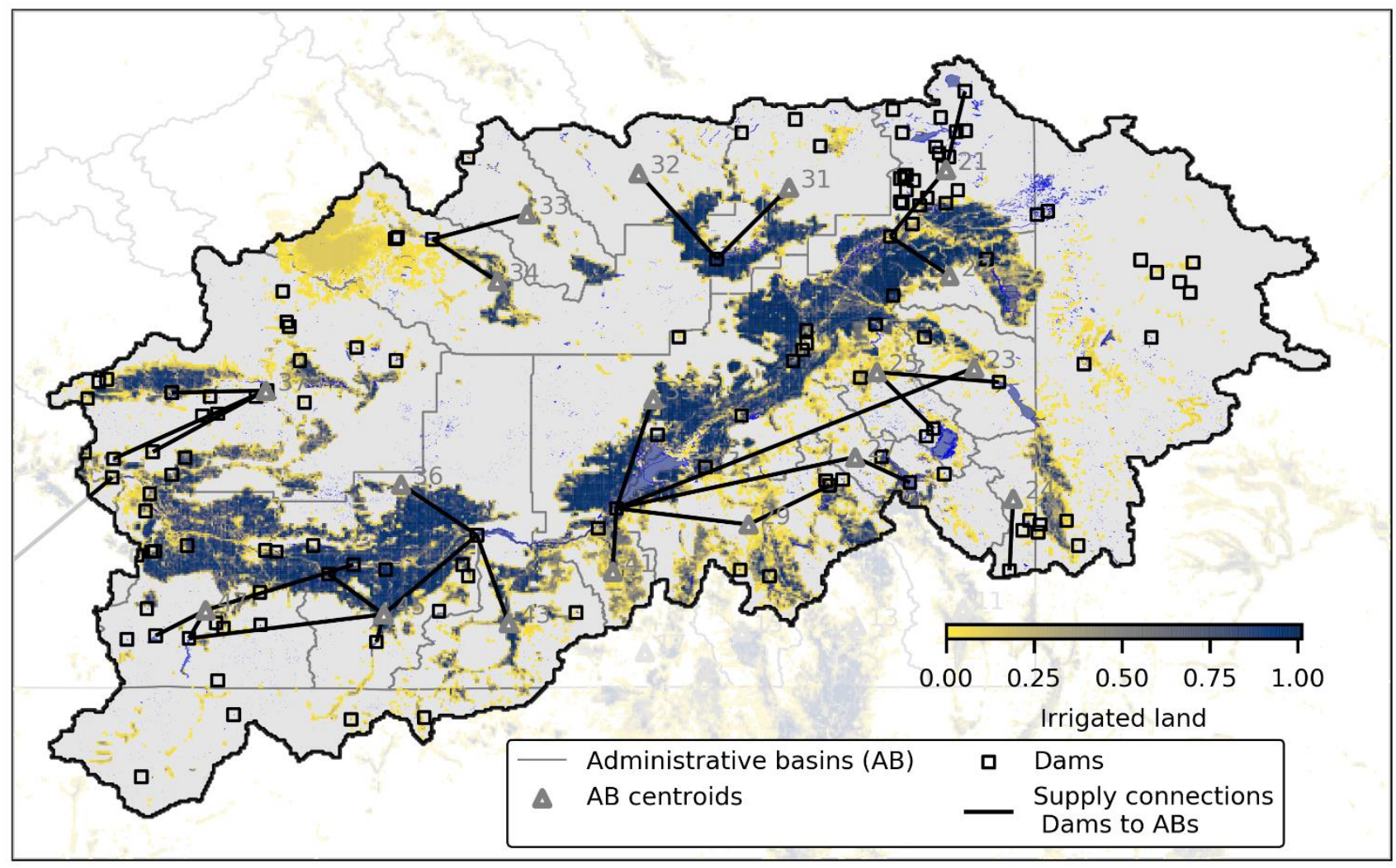

Figure S2: Map showing Idaho administrative basins, dam locations, connections between specific dams and administrative basins used for provisioning surface water, and total irrigated lands as a fraction of pixel area. Mapping specific reservoirs to each AB was done manually by tracing canal courses from National Hydrography Data (nhd.usgs.gov) from reservoirs through irrigated areas.

5 In addition, we derived irrigation water for AB 23 (eastern border of Idaho) from American Falls Reservoir because abstractions from this area of the state are taken below Palisades Reservoir, the next downstream reservoir is American Falls.

\section{Irrigation technology and modernization}

Irrigation technology was revised in the UNH Water Balance Model (WBM) to a process-based representation as an alternative to the prior conceptual formulation where non-beneficial fates were specified as a fraction of gross irrigation (Grogan et al.,

10 2017; Wisser et al., 2008, 2010). The process-based formulation redistributes inefficient irrigation water via surface runoff flows, groundwater percolation, and evaporation during both delivery and application stages. The system explicitly represented non-consumptive losses using technology specific parameters applied to proportions of irrigated croplands operating each technology. Losses during delivery were calculated from conveyance surface area (as a fraction of irrigated cropland), daily open water evaporation, and percolation. Conveyance methods included pipes with no evaporation or

15 percolation, and open conveyances such as canals and ditches that percolate at a fraction of local infiltration rates and evaporate from their surfaces. Incidental losses during application follow Jägermeyr et al. (2015) and use the distribution uniformity parameter that described excess water needed to satisfy net irrigation demand based on the type of technology, either drip, 
sprinkler, or flood. The distribution uniformity parameter was maintained at the values originally estimated for surface/flood, sprinkler, and direct/drip agriculture (Jägermeyr et al., 2015).

The process of calculating non-beneficial use $(N)$ and non-consumptive returns $(L)$ via application of irrigation water is performed throughout the WBM time-step cycle. Following calculation of net crop water demand $\left(I_{n e t}\right)$, additional delivery

5 and application requirements are calculated accounting for technology specific inefficiencies. Then, an initial estimate of delivered water is based on estimated water availability and if available water is determined to be insufficient to meet demand (plus inefficient use and loss), all associated irrigation fluxes are scaled downward linearly by the provisional irrigation supply factor $\left(X_{\text {irr }}\right)$. At this stage, WBM performs the river routing calculation, and estimates of provided water are updated according to actual water availability. Finally, excess water introduced to irrigated crop fields is partitioned between non-beneficial

10 evaporation, non-consumptive runoff, and non-consumptive percolation. What follows is a more detailed description of each of these steps. Unless specified otherwise, all calculations described in this section are distributed spatially across irrigated crop areas as grid operations.

WBM can run any number of individual technologies simultaneously using data of irrigated land fraction for which each of the technologies is used

$15\left\{\begin{array}{l}\sum_{i} f_{i}^{d, i r r}=1 \\ \sum_{i} f_{i}^{a, i r r}=1\end{array}\right.$

where $f_{i}^{d, i r r}$ and $f_{i}^{a, i r r}$ are fraction of land served by technology $i$ within irrigated land, and superscripts $d$ and $a$ denotes delivery and application technology group, respectively.

\subsection{Irrigation Delivery}

Inefficient fluxes from conveyances rely on calculated daily open water evaporation rates (function of air temperature,

20 humidity, and wind speed), and percolation rates of saturated soil. These rates are spatially and temporally distributed to the fraction of surface area of the irrigation delivery system $\left(f_{i}^{d, A}\right)$ relative to the irrigated area $\left(A^{i r r}, \mathrm{~m}^{2}\right)$ for each $i$ delivery technology. These non-beneficial fluxes are calculated at each pixel on each day crops demand irrigation water. Crop water demand functionality of WBM is described by Grogan et al. (2017). We assume that there is no surface runoff from any irrigation water delivery technology.

25 Evaporation of delivery water $\left(N_{\text {evap }}^{d}\right)$ is calculated for days when irrigation demand is required as

$N_{\text {evap }}^{d}=A_{f w} E_{f w}$

where $E_{f w}$ is evaporation rate from free water surface $(\mathrm{m} / \mathrm{d})$, and $A_{f w}$ is a weighted calculation of the pixel area undergoing free water evaporation through irrigation delivery systems:

$A_{f w}=A^{i r r} \sum_{i}^{n} f_{i}^{d, i r r} f_{i}^{d, A} \varepsilon_{i}^{\text {evap }}$ 
where $f_{i}^{d, A}(-)$ is the fraction of area relative to irrigated area that irrigation delivery systems occupy on the ground, and $\varepsilon_{i}(-)$ is a parameter that describes the fraction of an irrigation delivery technology that experiences free-surface evaporation. For the $\varepsilon_{i}^{\text {evap }}$ parameter we suggest using values approaching 1.0 for ditch and canals (because both have water surface exposed for evaporation), and approaching 0.0 for pipe delivery technology as the only water exposed to air for evaporation in pipes

5 consists of pipe leakage. All parameters can be spatially explicit; however, in our representation of the USRB only $A^{\text {irr }}$ is spatially explicit; total irrigated areas and the fraction of delivery technologies are described in the main text. The fraction of canal areas are modified by the technology parameterizations (main text). The fraction of area coverage in the presence of a specific delivery type $\left(f_{i}^{d, A}\right)$ and is assumed to be $1.2 \%$ for canals, which equates to an average $8 \mathrm{~m}$ wide canal traversing pixels that are completely irrigated. Defining spatially explicit estimates of canal coverage was beyond the scope of this study;

10 but may be an important consideration for refinement of the baseline model.

Percolation is calculated from unlined irrigation conveyance (canal or ditch) benthic surface in a method similar to the calculation for evaporation.

$L_{\text {perc }}^{d}=A_{\text {perc }} P_{\text {perc }}$

where $P_{\text {perc }}$ is percolation rate from the base of an irrigation delivery system to saturated soil, and $A_{\text {perc }}$ is a weighted

15 calculation of the pixel area undergoing saturated canal percolation under irrigation delivery systems:

$A_{\text {perc }}=A^{i r r} \sum_{i}^{n} f_{i}^{d, i r r} f_{i}^{d, A} \varepsilon_{i}^{\text {perc }}$

where $\varepsilon_{i}^{\text {perc }}$ fraction of canal area to which percolation is applied by technology $i$. For the $\varepsilon_{i}^{\text {perc }}$ parameter we suggest using 1.0 for ditch (no lining at the bottom of the ditch), a value representing the fraction of canal bottom areas in the domain that are un-lined (e.g. 1 for canals assuming $100 \%$ of bottom area are exposed to percolation in the e.g. USRB), and zero for

20 pipe delivery technology as its water is isolation from percolation in pipes. The percolation factor for canals is adjusted in our technology parameterizations (main text). The $P_{\text {perc }}$ rate is a specified parameter described in the main text.

Both $N_{\text {evap }}^{d}$ and $L_{\text {perc }}^{d}$ are scaled by the provisional supply factor $\left(X_{i r r}\right)$. It should be noted that $L_{\text {perc }}^{a}$ is introduced to the model at the location of the irrigated fields and not explicitly at the locations of canals. Furthermore, water that percolates beneath canals is considered a non-consumptive loss associated with irrigated agriculture, and is therefore a component of

25 irrigation reuse $(R)$ described in the main text.

\subsection{Irrigation Application}

Process-based modelling of irrigation water losses by application technology is implemented following an approach similar to Jägermeyr et al. (2015). Differences between the two approaches reflect additional processes introduced here, as well as accommodating unique structures of the two hydrologic models.

30 The first stage of estimating inefficient fluxes during application of irrigation water is to estimate inefficient runoff from excess application, which follows calculation of crop irrigation requirement, and concurrent with estimation of inefficient delivery 
fluxes $N_{\text {evap }}^{d}$ and $L_{\text {perc }}^{d}$. Excess irrigation supply $\left(I^{a}\right)$, analogous to the Application Requirements $(A R)$ parameter of Jägermeyr et al. (2015), is calculated for each crop group ( $k$, which can be either specific crop functional groups or pre-processed average land-cover groups described below):

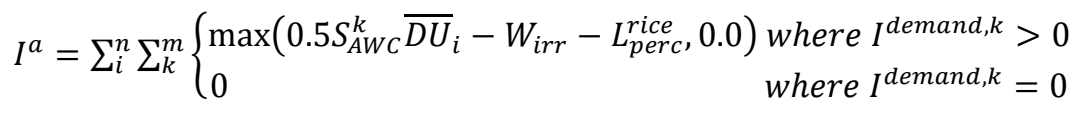

5 where $S_{A W C}^{k}$ is a grid of crop $(k)$ specific available water capacity $(\mathrm{mm})$ that accounts for soil properties, $\overline{D U}_{i}$ is the application technology specific distribution uniformity coefficient (Jägermeyr et al., 2015), $W_{i r r}$ is the storage in the irrigation runoff retention pool (whose balance is calculated like the surface retention surface runoff pool of WBM, but applies only to the irrigated pixel fraction), and $L_{\text {perc }}^{\text {rice }}$ is percolation associated with rice paddies, which is calculated separately (Grogan et al., 2017) and only applies over pixels with identified rice paddy, and $I^{\text {demand,k }}$ is the crop group specific irrigation demand.

10 Existing storage in the irrigation runoff retention is subtracted assuming that irrigation requirements are reduced by whatever volume exists in pixels above field capacity assuming that existing excess volume in the irrigation retention pool is shared by all crops at a given pixel. Soil porosity defining soil saturation above field capacity is not presently a parameter input to WBM; therefore, we estimate the volume of additional water above field capacity that saturates soil as $0.5 S_{A W C}^{k}$. The distribution uniformity parameter $(\overline{D U})$ is a fraction of the crop field to which this soil saturation applies. $\overline{D U}$ for flood irrigation is close

15 to 1 (all the soil in a crop area gets saturated) while for sprinkler irrigation about half of the possible saturation volume is actually applied. In the case of drip irrigation, a very small amount of water goes above $W_{c a p}$ and so $\overline{D U}$ is very low.

A fraction $\left(\varepsilon_{\text {mist }}\right)$ of water delivered to irrigated crop fields can be lost non-beneficially above crop canopy from enhanced evaporation of, for instance, sprinkler mists. The flux of mist enhanced evaporation $\left(N_{\text {mist }}^{a}\right)$ is calculated for each technology $(i)$ :

$20 \quad N_{\text {mist }}^{a}=\left(I^{a}+I^{\text {demand }, k}\right) \varepsilon_{\text {mist }}$

Parameterization of $\varepsilon_{\text {mist }}$ depends on local climate and specifics of sprinkler technology such that they can vary widely from 0 to $40 \%$, with most analyses estimating losses to be less than about 5\% (Bavi et al., 2009; McLean et al., 2000; Uddin et al., 2010). For the present study, we kept $\varepsilon_{\text {mist }}$ at a constant value of $4 \%$ considered reasonable for the semi-arid region of the USRB, but reflects an important area to consider for either refining baseline representation, or improving overall water resource 25 utilization (which we did not consider in this analysis).

Application and delivery inefficiencies are summed to net irrigation demanded by crops to estimate an initial gross irrigation flux $\left(G^{*}\right)$ :

$$
G^{*}=I^{\text {demand }}+I^{a}+N_{\text {mist }}^{a}+N_{\text {evap }}^{d}+L_{\text {perc }}^{d}
$$

30 A variety of functions are associated with sourcing available irrigation water in WBM, which yield a fraction of available water $\left(X_{i r r}\right.$ where $X_{i r r}=1$ indicates complete availability) from an appropriate distribution of sources. Typical irrigation source water determination is discussed in Grogan et al. (2017), and modified here to assign specific supply reservoirs to areas 
of the simulation (described below). Where water supply is less than complete $\left(X_{i r r}<1\right)$, all terms above are reduced linearly to utilize available supply via:

$I^{\text {demand }} *=X_{\text {irr }}$

$I^{a} *=X_{\text {irr }}$

$5 \quad N_{\text {mist }}^{a} *=X_{\text {irr }}$

$N_{\text {evap }}^{d} *=X_{\text {irr }}$

$L_{\text {perc }}^{d} *=X_{\text {irr }}$

Actual gross irrigation $(G)$ is calculated following routing later in the time-step, and small deviations between estimated and actual water availability are accounted for in subsequent timesteps.

10 Following routing through the stream network, the water balance of irrigation retention pool $\left(W_{i r r}\right)$ is updated using a stable solution and follows a conceptual order of flux priorities. The change in volume of $W_{i r r}$ is governed by the differential equation:

$\frac{d W_{\text {irr }}}{d t}=I^{a t m}+I^{a}-N_{\text {evap }}^{a}-L_{\text {perc }}^{a}-L_{\text {rnff }}^{a}$

where $I^{a t m}$ is water incident to irrigated crop fields from natural precipitation or melt, $N_{\text {evap }}^{a}$ is non-beneficial evaporation

15 from saturated soil surface, $L_{\text {perc }}^{a}$ is percolation from saturated soils to groundwater, and $L_{r n f f}^{a}$ is surface runoff from saturated soil. The stock of $W_{i r r}$ at the end of the timestep is calculated in four independent steps (denoted by superscripts):

1) $W_{i r r}^{1}=W_{i r r}^{0}+I^{a t m}+I^{a}$

2) $N_{\text {evap }}^{a}=\min \left(A_{\text {irr }} \overline{D U} \times E_{p}, W_{\text {irr }}^{1}\right)$

$W_{\text {irr }}^{2}=W_{\text {irr }}^{1}-N_{\text {evap }}^{a}$

20

3) $L_{\text {perc }}^{a}=\min \left(A_{\text {irr }} \overline{D U} \times P_{\text {perc }}, W_{\text {irr }}^{2}\right)$

$W_{\text {irr }}^{3}=W_{\text {irr }}^{2}-L_{\text {perc }}^{a}$

4) $L_{r n f f}^{a}=\min \left(A_{\text {irr }} \beta_{\text {surf }} \times \sqrt{2 g} \times \frac{W_{i r r}^{3}}{A_{i r r}}, W_{\text {irr }}^{3}\right)$

$W_{i r r}=W_{i r r}^{3}-L_{r n f f}^{a}$

where $W_{i r r}^{0}$ is the stock of the water retention pool at the end of the previous timestep, $E_{p}$ is the potential evapotranspiration

$25(\mathrm{~mm} / \mathrm{d}), \beta_{\text {surf }}$ is the parameter describing the rate of leakage from the irrigation (and surface) retention pools, and $g$ is the constant of gravitational acceleration. The order of updating the irrigation retention pool gives first precedence to nonbeneficial evaporation, and lowest precedence to surficial runoff, so non-consumptive losses may biased low. The proportions of delivery technologies were spatially homogenous and reflected the average lengths of technologies in the USGS National Hydrography Dataset (nhd.usgs.gov). The relative proportions of application technology varied by county following USGS 30 surveys (Dieter et al., 2018; Maupin et al., 2014). 


\section{Lumped aquifer representation}

New functionality was introduced to WBM to account for large aquifers using a lumped aquifer representation with unidirectional vertical movement. Lumped aquifers can be represented over all or portions of the model domain. Recharge percolating through the root zone is proportioned between shallow groundwater $\left(\gamma_{S G W}\right.$ between 0.05 and 0.08$)$ and the deeper

5 (lumped) aquifer $\left(\gamma-\gamma_{S G W}\right)$ at each pixel overlying an identified aquifer. Additionally, inflows from the surface flow network can be specified as point-based losing reaches that infiltrate directly to the aquifer (bypassing the shallow groundwater pool); flows to the ESPA are parameterized as a fraction of daily flow. Outflows from the aquifer occur as springs represented as points with head-dependent conductance similar to drains in MODFLOW (Harbaugh, 2005). Average head within the lumped aquifer head is calculated as:

$10 h=\frac{s_{A}}{C_{A}} * Z_{A}+Z_{0}$,

where $h$ is aquifer head $(m), S_{A}$ is the volume stored within the aquifer $\left(\mathrm{km}^{3}\right), C_{A}$ is the capacity of the aquifer $\left(\mathrm{km}^{3}\right)$ (so the ratio of $\frac{S_{A}}{C_{A}}$ is the fractional storage), $Z_{A}$ is the aquifer thickness $(m)$ and $Z_{0}$ is the base elevation $(m)$. Drainage through individual springs $\left(Q_{s p r}\right)$ is calculated as:

$Q_{s p r}=K_{s p r}\left(h-Z_{s p r}\right)$,

15 where $K_{s p r}$ is an individual spring's conductance $\left(m^{2} d^{-1}\right)$, and $Z_{s p r}$ is the elevation of each spring $(m) . Q_{s p r}$ is then summed for all individual springs. All recharge to and abstractions from the aquifer are summed through the previous day and mass balance of the aquifer is updated at a daily time-step using a Runge-Kutta 3(2) order (Bogacki-Shampine) scheme. Under this split operator solution, water percolating to and pumped from the aquifer is assumed to influence aquifer volume following a one day lag. The single-day lag is expected to underestimate percolation travel-times through the unsaturated zone and the

20 far-field hydrodynamic response of the aquifer to changes in pumping. The volume of water represented by the lumped aquifer model is assumed not to interact with shallow or root zone water (i.e. head is assumed to remain below the base of these zones) and fluxes from the aquifer to these zones are neglected. In the USRB, this is a reasonable assumption over most of the aquifer where vadose zones are fairly thick and dry (Whitehead, 1992).

The extent of the lumped aquifer was the same as that used for the ESPAM2 (IDWR, 2013). We represented the aquifer as

25 two lumped compartments (Figure 1b) to reflect the two types of water identified by Plummer et al. (2000), such that the ESPA was disaggregated to upgradient (northeast) and downgradient (southwest) sections just upgradient of Magic Valley irrigated croplands. Inflows into the upgradient portion consisted of natural recharge, percolation as reach gains from six losing rivers of the surface flow network (Big Lost, Little Lost Rivers, Birch, Medicine Lodge, Camas Creeks, and the Snake River), and incidental recharge from irrigation. The downgradient portion received flow from upgradient portion of the ESPA,

30 as well as natural and incidental recharge. Storage parameters were established from several sources (Garabedian, 1992; IDWR, 2013; Whitehead, 1992). For the upgradient section (Group 1 of Plummer), we selected a specific yield (0.06) and thickness of the aquifer $\left(250 \mathrm{~m}\right.$ ) comparable to these studies resulting in an average aquifer storage of about $\sim 330 \mathrm{~km}^{3}$, which 
is less than half of estimates of the total recoverable water volume of the aquifer (Robertson et al., 1974). The downgradient portion of the ESPA was attributed with a specific yield of 0.05 and thickness of $220 \mathrm{~m}$ resulting in an average storage of about $73 \mathrm{~km}^{3}$.

Springs draining the ESPA came from a detailed study of the Thousand Springs region between Twin Falls and King Hill, ID

5 (Covington and Weaver, 1991). Elevations of the springs decrease linearly along a westward head gradient, and spring elevations input to WBM subtracted out this average gradient such that each spring elevation only reflected deviations from an average head elevation of $828 \mathrm{~m}$. In other examples of spatially lumped aquifers (e.g. Famiglietti and Wood, 1994; van der Velde et al., 2009), statistical or functional accounting for spatial differences in the water table are used adding additional dynamism not simulated here. However, the majority of points of discharge from the ESPA are at known elevations that

10 follow a longitudinal gradient. Therefore, the linear transformation of the outlet elevation of the springs is simplifications appropriate to the ESPA where likely geostatistical or functional methods are more appropriate for spatially distributed water tables in the absence of specific known points of groundwater outflow.

The ESPA is known to be hydraulically connected to the ESPA in the vicinity of the American Falls Reservoir (Garabedian, 1992; IDWR, 2013), which we represent with an additional surface flow sink from the Snake River just upstream of American

15 Falls Reservoir to the upgradient ESPA aquifer, and a spring from the ESPA back to the Snake River at the reservoir. Parameterizing these flow paths was conducted manually primarily by matching the time-series of storage with the American Falls reservoir. Managed aquifer recharge to the ESPA was parameterized as an increased fraction of flow entering ESPA from the Snake River just upstream of American Falls.

\section{Crop classifications}

20 Crop Data Layer (CDL - Han et al., 2012) provided spatiotemporally explicit data for crop cover in our simulation domain; however, we utilized crop parameterizations from Monthly Irrigated and Rainfed Crop Atlas (MIRCA2000 - Portmann et al., 2010) to simulate crop water use (Grogan et al., 2017). To utilize CDL, we remapped crops according to the groupings in Table S1. Moreover, for simulations presented here we pre-processed these crop data to calculate weighted averages of each of the fundamental parameters associated with crop water use for rainfed and irrigated crops. Calculations of irrigation

25 demand, or inefficient irrigation water utilize either crop specific parameters or the average parameters with no fundamental change in calculation method, totals of all fluxes remain the same; however, attribution of water fluxes to specific crops is not possible when averaged inputs are used. Crop parameterization follows Portman et al. (2010) and Siebert and Döll (2010). 
Table S1 - Crop parameters used in study including crop data layer (CDL) crop identifiers as mapped to MIRCA2000 (Monthly Irrigated and Rainfed Crop Atlas) crops and associated planting parameters. Parameters of season length $\left(L_{\text {ini }}, L_{\text {dev }}, L_{\text {mid }}, L_{\text {late }}\right)$ and crop factors $(K c)$ at various stages in the growing season, and crop depletion factor (CDF), are as defined by Grogan et al.(2017) and Siebert and Döll (2010).

\begin{tabular}{|c|c|c|c|c|c|c|c|c|c|c|c|}
\hline Crop & MIRCA ID & CDL ID & $\mathbf{L}_{\mathrm{ini}}$ & $\mathbf{L}_{\operatorname{dev}}$ & $\mathbf{L}_{\text {mid }}$ & $\mathbf{L}_{\text {late }}$ & $\mathbf{K c}_{\mathbf{i}}$ & $K \mathbf{c}_{\mathbf{m}}$ & $K \mathbf{c}_{\mathrm{e}}$ & $\begin{array}{l}\text { Root Depth } \\
\quad(\mathbf{m m})\end{array}$ & $\mathrm{CDF}^{1}$ \\
\hline Wheat & 1 & $22-24,30$ & 0.15 & 0.25 & 0.40 & 0.20 & 0.40 & 1.15 & 0.30 & 1250 & 0.55 \\
\hline Maize & 2 & $1,12,13$ & 0.17 & 0.28 & 0.33 & 0.22 & 0.30 & 1.20 & 0.40 & 1000 & 0.55 \\
\hline Barley & 4 & 21 & 0.15 & 0.25 & 0.40 & 0.20 & 0.30 & 1.15 & 0.25 & 1000 & 0.55 \\
\hline Potatoes & 10 & 43 & 0.20 & 0.25 & 0.35 & 0.20 & 1.15 & 0.50 & 0.40 & 400 & 0.35 \\
\hline Sugarbeet & 13 & 41 & 0.20 & 0.25 & 0.35 & 0.20 & 0.35 & 1.20 & 0.80 & 700 & 0.55 \\
\hline Canola & 15 & $31,34,38$ & 0.30 & 0.25 & 0.30 & 0.15 & 0.35 & 1.10 & 0.35 & 1000 & 0.60 \\
\hline Pulses & 17 & $42,51,52,53$ & 0.18 & 0.27 & 0.35 & 0.20 & 0.45 & 1.10 & 0.60 & 550 & 0.45 \\
\hline Other Perennial & 24 & + & 0.00 & 0.00 & 1.00 & 0.00 & 1.00 & 1.00 & 1.00 & 800 & 0.50 \\
\hline Fodder Grasses & 25 & $36,37,58-60$ & 0.00 & 0.00 & 1.00 & 0.00 & 1.00 & 1.00 & 1.00 & 1500 & 0.55 \\
\hline Other Annual & 26 & ++ & 0.15 & 0.25 & 0.40 & 0.20 & 0.40 & 1.05 & 0.50 & 1000 & 0.55 \\
\hline 1 & \multicolumn{11}{|c|}{ Crop depletion factor } \\
\hline+ & \multicolumn{11}{|c|}{$55,56,66-68,71,74-77,204,210,211,216-218,220,221,223,242,250$} \\
\hline++ & \multicolumn{11}{|c|}{$11,14,25,28,32,33,35,39,44,46-50,54,57,205-209,213,214,219,222,227,229,231,243-249$} \\
\hline
\end{tabular}

\section{Spring outflow data}

Outflow of the Eastern Snake Plain Aquifer (ESPA) to the Snake River along the margins of the Snake River canyon consist predominately of flow out of large springs $\left(Q_{\text {spring }}\right)$. Spring out flows were provided by J. Sukow (pers. comm., updated from Sukow, 2012) which are calculated as

$10 Q_{\text {spring }}=Q_{4500}-Q_{0000}-Q_{8150}-Q_{2500}-Q_{s s}-Q_{N R f}+Q_{\text {Div }}$

Where $\mathrm{Q}_{4500}$ is the Snake River discharge at King Hill (USGS 13154500), Q 0000 is Snake River discharge at Kimberly (USGS 13090000), Q 8150 Salmon Falls Creek discharge (13108150), Q 2500 is Malad River discharge (USGS 13152500), Qss is discharge from the South Side canal system, $Q_{\text {NRf }}$ is discharge from the North Side canal return flows, and QDiv $_{\text {are diversions }}$ from the Snake River between the two reaches. Data provided by J. Sukow contain provisional and interpolated estimates for

15 some flow components.

\section{Validation of Water Balance Model for baseline}

County-wide gross and surface irrigation in 2010 and 2015 simulated by WBM (Figure S3) was biased low from USGS estimates (-34.9\%). The NSE of 0.267 signifies that the spatial variability in irrigation demand was captured despite the low bias. USGS USCO records counties at which diversions were made (Dieter et al., 2018), and WBM tracks counties at which

20 water was used, a discrepancy likely responsible for some of the error. WBM predicted the long-term mean in spring discharge from the ESPA with a percent bias (PBias) of $-0.78 \%$ but under-predicted seasonal variability (Figure S4), leading to a low 
NSE (0.112). Seasonal storage within the three Snake River reservoirs (Figure S5) using observed discharge at the reservoir outflow was accurate at the headwaters of the Snake River in Wyoming (Jackson Lake), though the representation departed from observations downstream (Palisades, and American Falls), which was attributed to cascading errors in both structure and input precipitation through the network. During the simulation period, overall performance of reservoir volume was

5 characterized with a negative NSE but a PBIAS of only 5.1\%. Seasonal discharge in headwaters of the Snake River (13010065, Snake River, Flagg Ranch, Wyoming) was accurately represented [NSE=0.9, PBIAS=5\%]; however, simulated discharge in smaller streams in the vicinity of the ESPA (13137500, Trail Creek, Ketchum, ID, and 13039500, Henry's Fork, Lake Idaho) was generally biased high, and exhibited stronger seasonal cycling than observations (Figure 5b). The high bias, and exaggerated seasonal cyclicity in discharge is a common observation of WBM's representation of small watersheds; additional

10 damping of discharge occurs through routing through the river network and especially at dams. Both Trail Creek and Henry's Fork have dammed reservoirs upstream of the gaging stations, and simulations may have underestimated the influence of dam operations.

Table S2: Summary of observations used for assessing model performance at baseline. Seasonal averages are calculated over meteorological seasons (Winter: DJF, Spring: MAM, Summer: JJA, Autumn: SON).

\begin{tabular}{|c|c|c|c|c|c|c|c|}
\hline Metric & Location and timestep of observation & unit & $\begin{array}{l}\text { Number of } \\
\text { observation }\end{array}$ & PBIAS & MPE & NSE & RMSE \\
\hline $\begin{array}{l}\text { Discharge from } \\
\text { springs }\end{array}$ & $\begin{array}{l}\text { Monthly sum of discharge from } \\
\text { springs (2008-2015), missing } 15 \\
\text { months } \\
\text { Annual sums for } 24 \text { USRB counties for }\end{array}$ & $\mathrm{m}^{3} / \mathrm{month}$ & 69 & -0.78 & -0.6 & 0.112 & 55,000 \\
\hline $\begin{array}{l}\text { Gross and surface } \\
\text { irrigation }\end{array}$ & $\begin{array}{l}\text { total and surface supply (2010 and } \\
\text { 2015) }\end{array}$ & $\mathrm{km}^{3} /$ year & 96 & -34.9 & -31.8 & 0.267 & 0.369 \\
\hline $\begin{array}{l}\text { Headwater } \\
\text { discharge }\end{array}$ & $\begin{array}{l}\text { Seasonal means for } 3 \text { stations } \\
\qquad(2008-2015)\end{array}$ & $\mathrm{m}^{3} / \mathrm{s}$ & 84 & 30.1 & 354 & 0.396 & 9.54 \\
\hline $\begin{array}{l}\text { Reservoir } \\
\text { storage }\end{array}$ & $\begin{array}{l}\text { Seasonal means for } 3 \text { reservoirs } \\
\qquad(2008-2015)\end{array}$ & $\mathrm{m}^{3}$ & 84 & 5.07 & 13.4 & -0.409 & $4.5 \mathrm{E}+08$ \\
\hline
\end{tabular}

Note: PBIAS: percent bias, MPE: model percent error, NSE: Nash-Sutcliffe efficiency, RMSE: root mean squared error. 


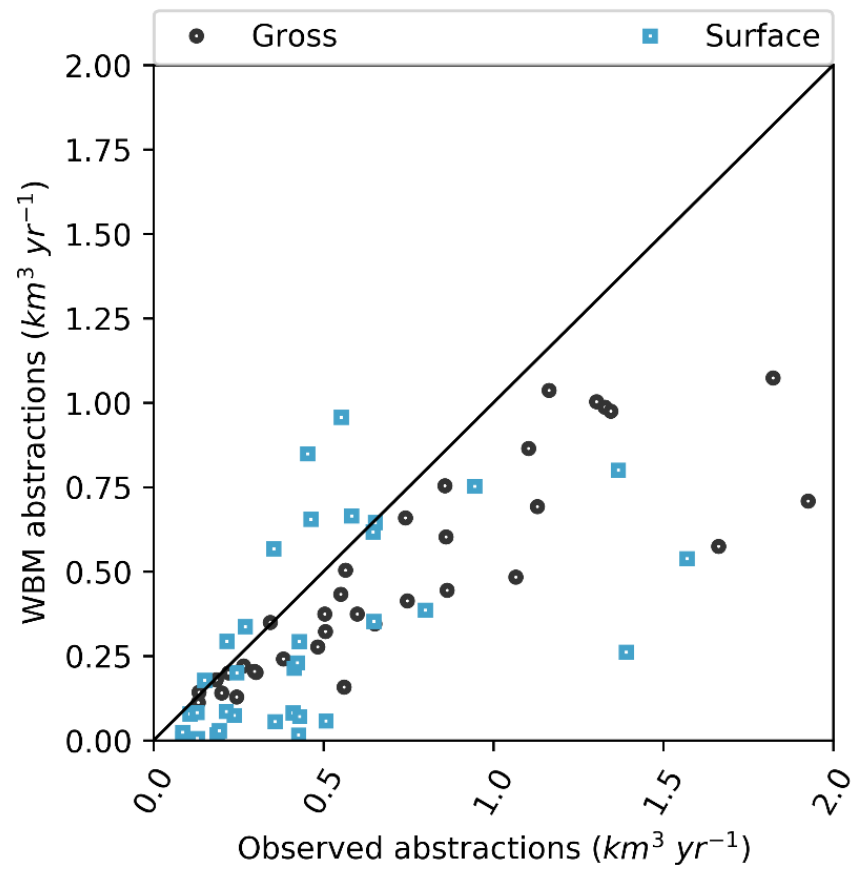

Figure S3: Correlation between model (y) and USGS estimated county-wide gross (a) and surface water (b) irrigation water use in 2010 and 2015.

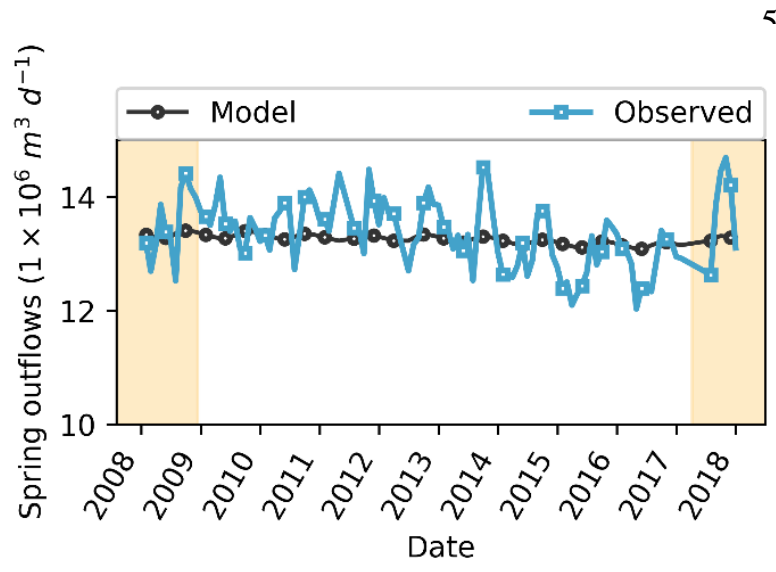

15 Figure S4: Time-series of spring discharges. 
a)

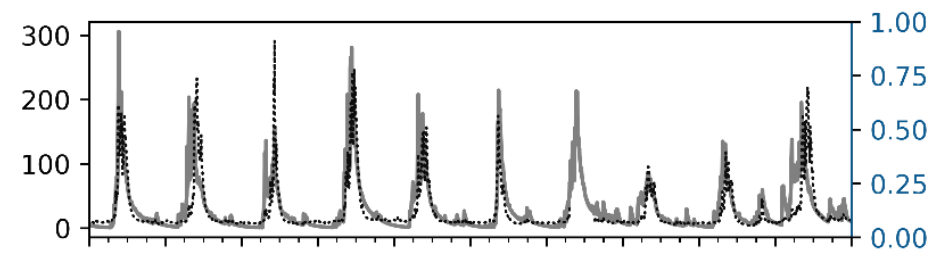

b)

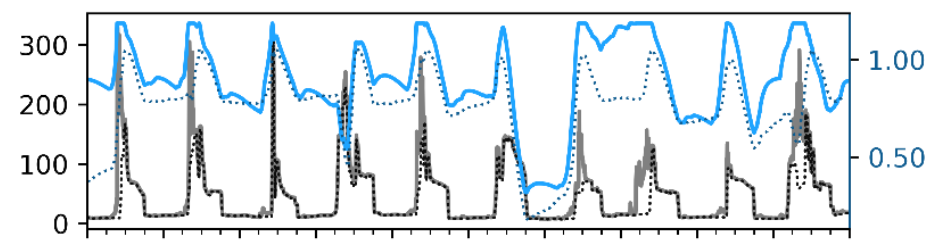

c)

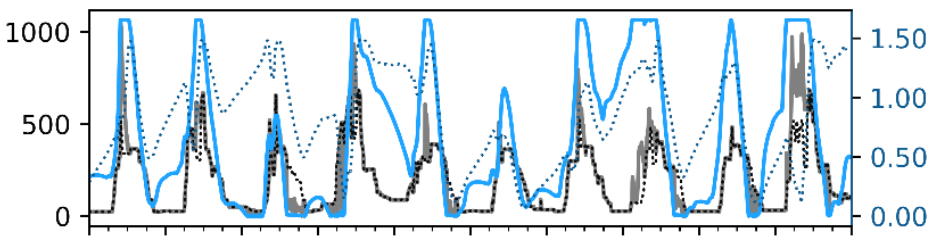

d)
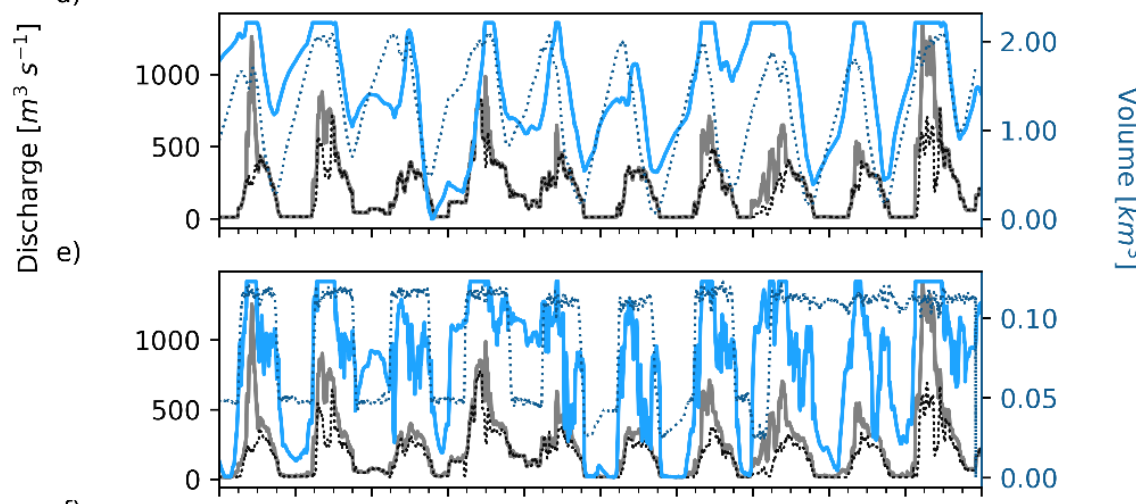

f)

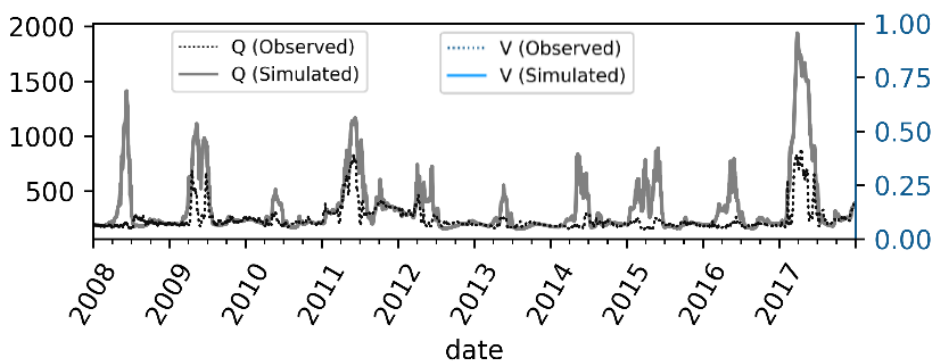

Figure S5: Time series of discharge and reservoir volume at six locations on the Snake River. WBM predictions as solid lines, observations as dotted lines. Reservoir volume (blue) observations from the USBR HydroMet network, and discharge (black/gray) from USGS gaging stations. Discharge gaging stations are located as close to immediately downstream of respective reservoirs. The six site locations (all on Snake River) and their respective USGS and USBR (for b-e) station identifiers, Nash-Sutcliffe efficiencies, and percent bias are (a) Flagg Ranch, WY (13010065: 0.72, 13.5\%), (b) Moran, WY and Jackson Lake (13011000: 0.63, 23\%, JCK: 0.04, 17\%), (c) Irwin, ID and Palisades Reservoir (13032500: 0.79, 5.0\%, PAL: -1.0, -22\%), (d) Neeley, ID and American Falls Reservoir (13077000: 0.42, 25\%, AMF: -0.05, 17\%), (e) Rupert, ID and Walcott Lake (13081500: -0.26, 52\%, MIN: -0.4,-20\%), and

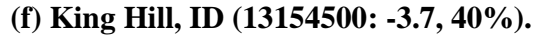



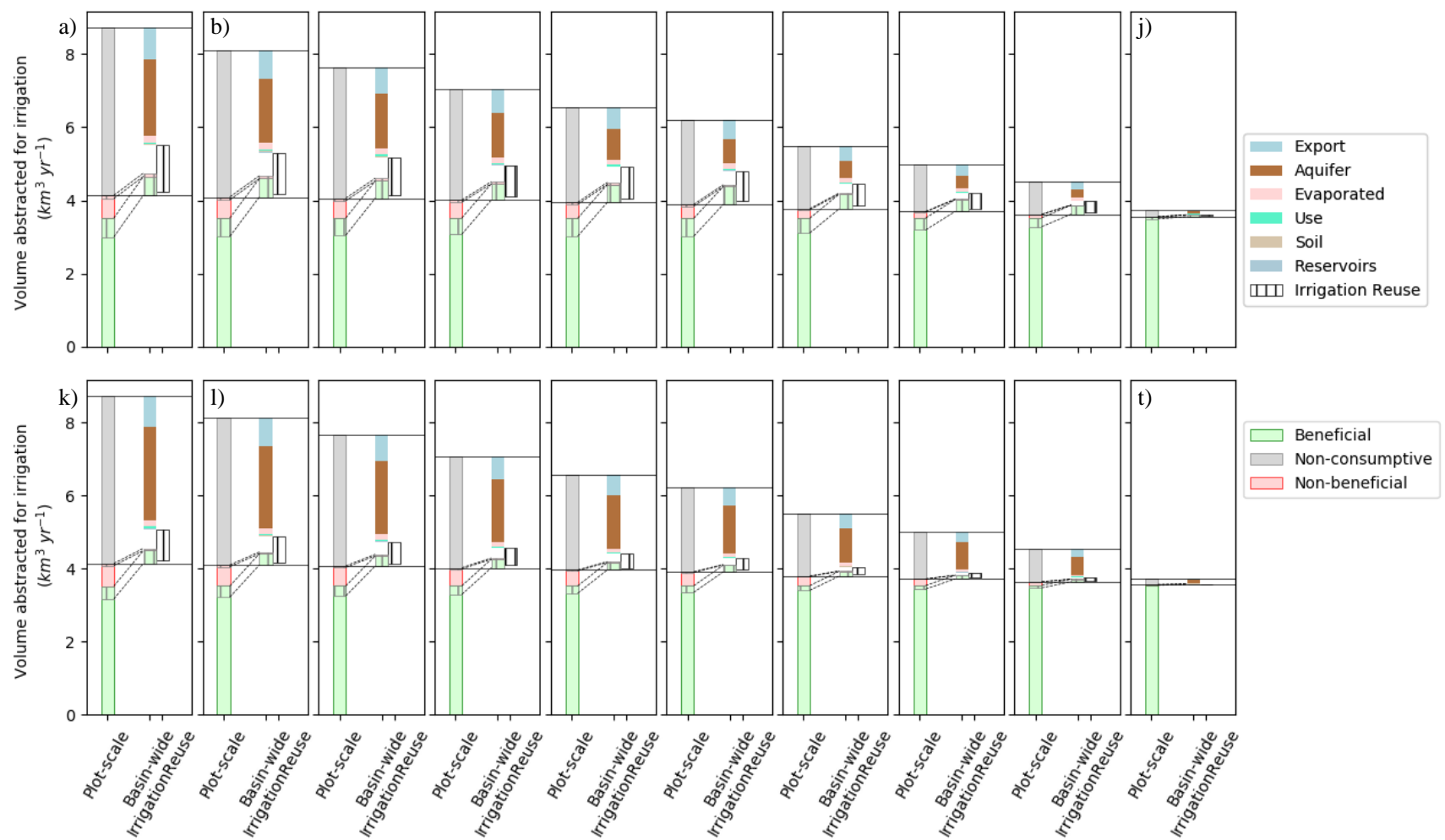

Figure S6: Comparison between component fraction (summed for basin) and irrigation return fates across the USRB under the all parameterizations. Top row (a-j) with enhanced aquifer recharge, bottom row without (k-t). Baseline technology in first column $(\mathbf{a}, \mathbf{k})$, and increasing modernization scenarios in subsequent columns (Eff.A:b,l, Eff.B:c,m, ... , Eff.I:j,t).

\section{References}

Bavi, A., Kashuli, H. A., Boroomand, S., Naseri, A. and Albaji, M.: Evaporation Losses from Sprinkler Irrigation Systems under Various Operating Conditions, Journal of Applied Sciences, 9(3), doi:10.3923/jas.2009.597.600, 2009.

Covington, H. R. and Weaver, J. N.: Geologic map and profiles of the north wall of the Snake River Canyon, Thousand Springs and Niagara quadrangles, Idaho, USGS Numbered Series, U.S. Geological Survey, Reston, VA. [online] Available from: http://pubs.er.usgs.gov/publication/i1947C, 1991.

Dieter, C. A., Maupin, M. A., Caldwell, R. R., Harris, M. A., Ivahnenko, T. I., Lovelace, J. K., Barber, N. L. and Linsey, K. S.: Estimated use of water in the United States in 2015, USGS Numbered Series, U.S. Geological Survey, Reston, VA. [online] Available from: http://pubs.er.usgs.gov/publication/cir1441 (Accessed 13 November 2018), 2018.

15 Famiglietti, J. S. and Wood, E. F.: Multiscale modeling of spatially variable water and energy balance processes, Water Resources Research, 30(11), 3061-3078, doi:10.1029/94WR01498, 1994. 
Garabedian, S. P.: Hydrology and digital simulation of the regional aquifer system, eastern Snake River Plain, Idaho, USGS Numbered Series, U.S. Government Printing Office. [online] Available from: http://pubs.er.usgs.gov/publication/pp1408F, 1992.

Grogan, D. S., Wisser, D., Prusevich, A., Lammers, R. B. and Frolking, S.: The use and re-use of unsustainable groundwater

Han, W., Yang, Z., Di, L. and Mueller, R.: CropScape: A Web service based application for exploring and disseminating US conterminous geospatial cropland data products for decision support, Computers and Electronics in Agriculture, 84, 111-123, doi:10.1016/j.compag.2012.03.005, 2012.

Harbaugh, A.: MODFLOW-2005, The U.S. Geological Survey Modular Ground-Water Model-the Ground-Water Flow

Process, in Book 6. Modeling techniques, Section A. Ground Water, vol. 6, p. 253, U.S. Geological Survey, Reston VA., 2005.

IDWR: Enhanced Snake Plain Aquifer Model Version 2.1: Final Report, Idaho Department of Water Resources, Boise ID., 2013.

Jägermeyr, J., Gerten, D., Heinke, J., Schaphoff, S., Kummu, M. and Lucht, W.: Water savings potentials of irrigation systems: global simulation of processes and linkages, Hydrol. Earth Syst. Sci., 19(7), 3073-3091, doi:10.5194/hess-19-3073-2015, 2015 .

Maupin, M. A., Kenny, J. F., Hutson, S. S., Lovelace, J. K., Barber, N. L. and Linsey, K. S.: Estimated use of water in the United States in 2010, U.S. Geological Survey, Reston, Virginia., 2014.

McLean, R. K., Ranjan, R. S. and Klassen, G.: Spray evaporation losses from sprinkler irrigation systems, Canadian Agricultural Engineering, 42(1), 8, 2000.

20 Plummer, L. n., Rupert, M. g., Busenberg, E. and Schlosser, P.: Age of Irrigation Water in Ground Water from the Eastern Snake River Plain Aquifer, South-Central Idaho, Ground Water, 38(2), 264-283, doi:10.1111/j.1745-6584.2000.tb00338.x, 2000.

Portmann, F. T., Siebert Stefan and Döll Petra: MIRCA2000 - Global monthly irrigated and rainfed crop areas around the year 2000: A new high-resolution data set for agricultural and hydrological modeling, Global Biogeochemical Cycles, 24(1), doi:10.1029/2008GB003435, 2010.

Robertson, J. B., Schoen, R. and Barraclough, J. T.: The influence of liquid waste disposal on the geochemistry of water at the National Reactor Testing Station, Idaho, 1952-1970, USGS Numbered Series. [online] Available from: http://pubs.er.usgs.gov/publication/ofr73238, 1974.

Siebert, S. and Döll, P.: Quantifying blue and green virtual water contents in global crop production as well as potential production losses without irrigation, Journal of Hydrology, 384(3), 198-217, doi:10.1016/j.jhydrol.2009.07.031, 2010.

\section{Sukow, J.: COMPARISON OF ENHANCED SNAKE PLAIN AQUIFER MODEL VERSION 2.1 WITH VERSION 1.1 VIA THE CURTAILMENT SCENARIO, 2012.}

Uddin, J., Smith, R., Hancock, N. and Foley, J. P.: Droplet evaporation losses during sprinkler irrigation: an overview, in Australian Irrigation Conference and Exibition 2010: Proceedings, edited by K. Montagu, pp. 1-10, Irrigation Australia Ltd., 35 Sydney, Australia. [online] Available from: http://www.irrigationaustralia.com.au/visitor.cfm?id=41 (Accessed 2 April 2019), 2010. 
van der Velde, Y., de Rooij, G. H. and Torfs, P. J. J. F.: Catchment-scale non-linear groundwater-surface water interactions in densely drained lowland catchments, Hydrol. Earth Syst. Sci., 13(10), 1867-1885, doi:10.5194/hess-13-1867-2009, 2009.

Whitehead, R. L.: Geohydrologic framework of the Snake River plain regional aquifer system, Idaho and eastern Oregon, USGS Numbered Series, U.S. Government Printing Office. [online] Available from:

5 http://pubs.er.usgs.gov/publication/pp1408B, 1992.

Wisser, D., Frolking, S., Douglas, E. M., Fekete, B. M., Vörösmarty, C. J. and Schumann, A. H.: Global irrigation water demand: Variability and uncertainties arising from agricultural and climate data sets, Geophysical Research Letters, 35(24), doi:10.1029/2008GL035296, 2008.

Wisser, D., Fekete, B. M., Vörösmarty, C. J. and Schumann, A. H.: Reconstructing 20th century global hydrography: a 10 contribution to the Global Terrestrial Network- Hydrology (GTN-H), Hydrology and Earth System Sciences, 14(1), 1-24, doi:10.5194/hess-14-1-2010, 2010. 